\title{
Terrorism in Pakistan: the psychosocial context and why it matters
}

\author{
Asad Tamizuddin Nizami, ${ }^{1}$ Tariq Mahmood Hassan,, ${ }^{2}$ Sadia Yasir, ${ }^{3}$ \\ Mowaddat Hussain Rana ${ }^{4}$ and Fareed Aslam Minhas ${ }^{5}$
}

${ }^{1}$ Assistant Professor, Institute of Psychiatry, World Health Organization Collaborating Centre for Mental Health, Benazi Bhutto Hospital, Rawalpindi Medical College, Rawalpindi, Pakistan; email drasadnizami@ ail drasadnizami@ gmail.com

${ }^{2}$ Assistant Professor, Providence Care Mental Health Services, Kingston, Canada

${ }^{3}$ Consultant Psychiatrist, Shifa International Hospital, Shifa College of Medicine, Islamabad, Pakistan

${ }^{4}$ Director General, Centre for Trauma Research and Psychosocial Interventions, National University of Sciences and Technology (NUST), and Technology (NUST),
Islamabad, Pakistan

${ }^{5}$ Head Institute of Psychiatry, World Health Organization World Health Organization
Collaborating Centre for Mental Health, Benazir Bhutto Hospital, Rawalpindi Medical College, Rawalpindi, Pakistan

Acknowledgements. We thank Tanya Tran from the Department of Psychology at Queen's University and Dr Sobia Haqqi Consultant Psychiatrist at Sir Syed Consultant Pychiatrist at Sir Syed Medical College in Karachi for their help in preparing part of this manuscript.

\section{Conflicts of interest. None.}

(c) The Authors 2018. This is an Open Access article, distributed under the terms of the Creative under the terms of the
Commons AttributionCommons Attribution-
NonCommercial-NoDerivatives licence (http://creativecommons. org/licenses/by-nc-nd/4.0/), which permits non-commercial re-use, distribution, and reproduction in distribution, and reproduction in the original work is unaltered and is properly cited. The written permission of Cambridge University Press must be obtained for commercial re-use or in order to create a derivative work.
Terrorism is often construed as a well-thoughtout, extreme form of violence to perceived injustices. The after effects of terrorism are usually reported without understanding the underlying psychological and social determinants of the terrorist act. Since '9/11' Pakistan has been at the epicentre of both terrorism and the war against it. This special paper helps to explain the psychosocial perspective of terrorism in Pakistan that leads to violent radicalisation. It identifies the terrorist acts in the background of Pakistan's history, current geopolitical and social scenario. The findings may also act as a guide on addressing this core issue.

Most nations are unable to reach a consensus on a legally binding definition of 'terrorism.' The term seems emotionally charged and, as such, governments have been devising their own definitions. So far the United Nations has been unable to devise an internationally agreed-upon definition of terrorism. Terrorism is suggested to be 'the use of intimidation or fear for advancement of political objectives' (Kruglanski \& Fishman, 2006). Since the ' $9 / 11$ ' incident, Muslim countries in particular feel emotionally threatened with the word terrorism and perceive it as synonymous with the acts of terror carried out by so-called Muslim extremist groups. This is further complemented in the media by the unjust linking of such horrendous terror attacks to Islamic Jihad.

Terrorism has brought an enormous burden on South Asian countries through the adverse impacts on their social, economic, political and physical infrastructure. Pakistan has suffered particularly excessively from the social, economic and human costs due to terrorism (Daraz et al, 2012). Surprisingly, Pakistan is portrayed as being on the front line in the international war against terrorism and at the same time has been wrongly labelled as a sponsor of international terrorism. Terrorism in Pakistan is a multidimensional phenomenon and, among many precipitating factors, the psychosocial factors play an important role. This paper attempts to address what we believe are significant psychosocial determinants to terrorism in Pakistan.

\section{Historical developments}

Pakistan is a Muslim majority nation in South East Asia with India to its east, Iran and Afghanistan to its west, China and the landlocked Asian countries to its north and the Arabian Sea to its south. Pakistan gained independence from British colonial rule in 1947 and is the only Muslim country with nuclear weapons - a nuclear device was detonated in 1998 - and is thus part of the informally named 'nuclear club.' Pakistan is a federation of four provinces (Punjab, Sindh, Khyber Pakhtunkhwa (KPK) and Balochistan), a capital territory (Islamabad) and a group of federally administered tribal areas in the north west, along with the disputed area of Azad Jammu and Kashmir.

Pakistan is the world's sixth most populous country with an average population density of 229 people per $\mathrm{km}^{2}$ (World Bank indicators; http://www.tradingeconomics.com/pakistan/urbanpopulation-growth-annual-percent-wb-data.html). Since independence in 1947, Pakistan has been challenged not only by the trauma inflicted by its colonial occupiers but also by the mass murder of people migrating to the 'new' country. Hundreds of thousands of people were killed, looted, raped or burnt alive. At the same time, the stability of this fledgling country was significantly hampered by the lack of resources. Just a few years later, due to political instability and separatist movements and terrorism, the east wing of the country was separated from Pakistan; this paved the way to the creation of a new country, Bangladesh, in 1971 (Wadhwani, 2011).

The Soviet-Afghan war, which began in 1979, provided a breeding ground for terrorism in the region. A fundamental change was witnessed that altered the very character of the existing Pakistani society. Withdrawal of the Soviets revealed a Pakistani society that had been forced into one of violence and weaponisation, plaguing Pakistan with so-called 'Kalashnikov culture' and 'Talibanisation' (Wadhwani, 2011).

Pakistan's social landscape has for the most part been plagued with illiteracy, disease, insecurity and injustice. Since the $9 / 11$ incident, Pakistan has been intricately linked with the many facets of the 'war on terrorism.' Some argue that Pakistan is a breeding ground for terrorist outfits, but it is certain that all of this havoc has resulted in the significant loss of innocent lives as well as loss of economic revenue. These fragile conditions provide a fertile ground for terrorism to grow.

\section{Psychological influence}

The act of carrying out terrorist activity does not come from a single moment of inspiration but 
rather from a complex process of cognitive accommodation and assimilation over accumulating steps. It is wrongly reductionist to label the terrorists as mad or psychopaths (Atran, 2003; Horgan, 2008). Terrorists' motivation may involve a deep, underlying quest for personal meaning and significance. Several analyses of such motives have appeared in recent years. There are differences in these analyses regarding the type and variety of motivational factors identified as critical to terrorism. Some authors identified a singular motivation as crucial; others listed a 'cocktail' of motives (Sageman, 2004; Bloom, 2005).

The socioeconomic adversity combined with political challenges were bound to have a detrimental impact on the psyche of the average Pakistani. A terrorist adopts a dichotomous way of identifying their victims, the black-and-white thought that 'I am good' and 'you are evil,' with no intermediary shades of grey. This thinking leaves no doubt in their minds and they find it easier to kill their opponents with little or no sense of remorse or guilt.

The unmanned army drone strikes killed and maimed thousands of innocent civilians in poor and difficult to access regions of Pakistan. This infuriated people, leading them to take up arms against the perceived aggressors. This triggering of the relatives of the deceased to engage in such activity is the culture of revenge in Pakistan, which unfortunately can last for generations.

Self-sacrifice and martyrdom has been explicitly used in almost all religions and is aggressively exploited by terrorist outfits who groom suicide bombers using the ideology of Islamist martyrdom (Atran, 2003). Some have argued that suicide bombers may actually be clinically suicidal and attempting to escape personal impasse (Lankford, 2013). In grooming young impressionable adolescents, extremist organisations brainwash these adolescents into believing that the ultimate self-sacrifice by suicide bombing will elevate their stature in the eyes of God and send them straight to heaven. This is associated with massive financial compensations to the deceased family. Terrorist organisations in Pakistan, through this process of brainwashing, have been able to convert young impressionable Muslim adolescents into a 'suicide bomber in six weeks' (Nizami et al, 2014). In the current scenario of the existing war on terror, this complex process of recruiting young adolescents as suicide bombers seems irreversible.

\section{The contribution of the religious schools}

In the West, Madrassas (Islamic religious schools) have gained a reputation of being a sinister influence on young impressionable Muslims. These institutions are not completely regulated and can vary from a single room to large institutions offering schooling and boarding to hundreds of students at a time. A survey of just over 50000 households in Pakistan found that children in
Urdu-medium government schools and madrassas were from poorer households than those in English-medium private schools. The primary reason for parents to send their children to madrassas as opposed to mainstream schools was that these institutions provided a good Islamic education. The second most common reason was that the madrassa provided education that is low in cost along with the provision of food and clothing (Cockcroft et al, 2009).

Another survey indicated that in Pakistan only a minority of the religious schools promoted an extremist view of Islam (Bano, 2007). An interrogation of 79 terrorists involved in anti-Western attacks found that very few had attended a madrassa. This suggests that terrorist groups may selectively recruit better qualified people for technically demanding tasks (Bergen \& Pandey, 2006). However, the religious seminaries have been implicated as playing the role of recruitment centres for the suicide bombers (Nizami et al, 2014).

In an effort to break this incorrect perception the Darul Uloom Deoband, the largest Islamic seminary in the world, hosted an anti-terrorist conference in 2008. This was attended by 6000 Imams declaring that 'Islam is a religion of mercy for all humanity. Islam sternly condemns all kinds of oppression, violence and terrorism. It has regarded oppression, mischief, rioting and murder among sins and crimes' (Press Trust of India, 2008). However, it is yet to be ascertained how many religious schools in Pakistan adopted this school of thought. With the revolution in the world of information technology, experts agree that the internet played an important role in the radicalisation and selfrecruitment process into terrorist groups. Messages and videos on jihadi websites target the 'soft spots' of potential recruits and inflame their imagination (Kruglanski \& Fishman, 2009).

\section{The link between terrorism and mental disorder}

With both mental disorder and terrorism in Pakistan being highly prevalent, it would be a fair assumption that the two may have a causal relationship. Walter Laqueur wrote that 'all terrorists believe in conspiracies by the powerful, hostile forces and suffer from some form of delusion and persecution mania... The element of... madness plays an important role in terrorism' (Silke, 2003).

However, apart from certain pathological cases, a causal connection between an individual's mental disorder and engagement in terrorist activity could not be established (Daraz et al, 2012). However, there can be a connection between an individual engaging in terrorist activity and developing a mental disorder as mental disorders worsen in stress, anxiety and depression.

The adverse impacts of terrorism lead the masses towards anomie and create the tendency 
towards suicide and mental illnesses (Daraz et al, 2012). Poor health, depressive symptoms, risky behaviours in young adults, personality variables, social inequalities, criminality, social networks and international foreign policy have all been proposed to be influential drivers for grievances that lead to radicalisation and terrorism ( $\mathrm{La}$ Free \& Ackerman, 2009).

It may well be that individuals with mild depression would be a better target for gradual psychological moulding. Female suicide bombers who are predominantly motivated by revenge as opposed to their male counterparts may have some degree of clinical depression (Jacques \& Taylor, 2008). Personality traits are useless as predictors for understanding why people become terrorists. However, personality traits and environmental conditions are the contributing factors for terrorism (Horgan, 2008). There are protective and modifiable risk factors early on the path towards radicalisation. The benefits of early intervention have far reaching implications for preventing significant depressive symptoms, promoting wellbeing and perhaps social capital (Bhui et al, 2014).

\section{Conclusion}

By understanding, appreciating and addressing the psychosocial factors contributing to terrorism in Pakistan, one may find long-lasting solutions to the fall out on Pakistan's war against terror. This war has led to a loss of innocent human lives, compounded by the deep psychological scars for survivors which will undoubtedly persist for generations to come. An ongoing, concerted effort to gain peace and security in the region is essential and is the only way to counteract the revenge attacks and further brainwashing of young impressionable youths. These psychological determinants, however, are markedly different than terrorist activities in Western countries, where it seems that a different set of psychological rules apply.

\section{References}

Atran S. (2003) Genesis of suicide terrorism. Science, 299, 15341539.

Bano M. (2007) Beyond politics: the reality of a deobandi madrasa in Pakistan. Islamic studies, 18, 43-68.
Bergen P. \& Pandey S. (2006) The madrassa scapegoat. Washington Quarterly, 29, 115-125.

Bhui K., Everitt B. \& Jones E. (2014) Might depression, psychosocial adversity, and limited social assets explain vulnerability to and resistance against violent radicalization? PLOS ONE, 9(9), e105918 (doi: 10.1371/journal.pone.0105918).

Bloom M. (2005) Dying to Kill. The Allure of Suicide Terror. Columbia University Press.

Cockcroft A., Andersson N., Milne D., et al (2009) Challenging the myths about madaris in Pakistan: a national household survey of enrolment and reasons for choosing religious schools. International Journal of Educational Development, 29, 342-349.

Daraz U., Naz A. \& Khan W. (2012) Sociological analysis of terrorism in Pakistan. Academic Research International, 3(1).

Horgan J. (2008) From profiles to pathways and roots to routes: perspectives from psychology on radicalization into terrorism. The Annals of the American Academy of Political and Social Science, 618 (1), 80-94.

Jacques K. \& Taylor P. J. (2008) Male and female suicide bombers: different sexes, different reasons? Terrorism, 31, 304-326.

Kruglanski A. W. \& Fishman S. (2006) The psychology of terrorism: "syndrome" versus "tool" perspectives. Terrorism and Political Violence, 18, 193-215.

Kruglanski A. W. \& Fishman S. (2009) Psychological factors in terrorism and counterterrorism: individual, group, and organizational levels of analysis. Social Issues and Policy Review, 3, 1-44.

La Free G. \& Ackerman G. (2009) The empirical study of terrorism: social and legal research. Annual Review of Law and Social Science, 5 , 347-374.

Lankford A. (2013) The Myth of Martyrdom: What Really Drives Suicide Bomber, Rampage Shooters, and Other Self-Destructive Killers (1st edn). Palgrave Macmillan.

Nizami A. T., Rana M. H., Hassan T. M., et al (2014) Terrorism in Pakistan: a behavioral sciences perspective. Behavioral Sciences \& The Law, 32, 335-46.

Press Trust of India (2008) Muslim clerics declare terror "un-Islamic." The Times of India, 25 Feb. Available at http://timesofindia.indiatimes. com/india/Muslim-clerics-declare-terror-un-Islamic/articleshow/ 2813375.cms (accessed 6 July 2015).

Sageman M. (2004) Understanding terrorist networks. University of Pennsylvania Press.

Silke A. (2003) Becoming a terrorist. In Terrorists, Victims and Society: Psychological Perspectives on Terrorism and its Consequences (ed. A. Silke), John Wiley \& Sons.

Wadhwani R. (2011) Essay On Terrorism In Pakistan: Its Causes, Impacts And Remedies. Civil Service Pakistan Forum. 28 September 2011. Available at: http://www.cssforum.com.pk/css-compulsorysubjects/essay/essays/54746-essay-terrorism-pakistan-its-causesimpacts-remedies.html. 